\title{
Alpha-tocopherol and ergocalciferol contents of some macroalgae from Bulgarian Black Sea coast
}

\author{
Veselina PANAYOTOVA*a ${ }^{\mathrm{a}}$, Mona STANCHEVA ${ }^{\mathrm{a}}$ and Diana DOBREVA ${ }^{\mathrm{a}}$ \\ ${ }^{a}$ Department of Chemistry, Medical University of Varna, 55 Marin Drinov str., Varna, Bulgaria
}

\begin{abstract}
The aim of the present study was to determine and compare $\alpha$-tocopherol and ergocalciferol content in four macroalgae from Bulgarian Black sea coast. Ulva rigida, Cladophora vagabunda, Cystoseira barbata and Cystoseira crinita were used for evaluation of corresponding fat soluble vitamins content. The sample preparation procedure includes alkaline saponification, followed by liquid-liquid extraction. Ergocalciferol (vitamin $\mathrm{D}_{2}$ ) and $\alpha$-tocopherol (vitamin E) were analyzed simultaneously using HPLC/UV/FL system (Thermo Scientific Spectra SYSTEM) equipped with RP analytical column. The mobile phase was composed of 97:3 = $\mathrm{MeOH}: \mathrm{H}_{2} \mathrm{O}$. Ergocalciferol was monitored by UV detection at $\lambda \max =265 \mathrm{~nm}$, while $\alpha$-tocopherol was detected by fluorescence at $\lambda \mathrm{ex}=288 \mathrm{~nm}$ and $\lambda \mathrm{em}=332 \mathrm{~nm}$. Alpha-tocopherol content in algal tissues ranged from $1.68 \pm 0.38 \mathrm{mg} / 100 \mathrm{~g}$ d.w. in Cladophora vagabunda to $29.13 \pm 1.08 \mathrm{mg} / 100 \mathrm{~g}$ d.w. in Cystoseira barbata. Ergocalciferol was detected only in Ulva rigida samples.
\end{abstract}

Keywords: macroalgae, ergocalciferol, $\alpha$-tocopherol, HPLC

\section{Introduction}

Seaweeds belong to a group of plants known as algae. They are classified as Rhodophyta (red algae), Phaeophyta (brown algae) or Chlorophyta (green algae) depending on their pigments and chemical composition. Like other plants, seaweeds contain various inorganic and organic substances which can benefit human health. Algae have been used since ancient times as food, fodder, fertilizer and as source of medicine. Nowadays seaweeds represent an inexhaustible source of the raw materials used in pharmaceutical, food industries, medicine and cosmetics. They are nutritionally valuable as fresh or dried vegetables, or as ingredients in a wide variety of prepared foods. In particular, seaweeds contain significant quantities of protein, lipids, minerals and vitamins [1].

Seaweeds are a good source of some water- (B1, $\mathrm{B} 2, \mathrm{~B} 12, \mathrm{C})$ and fat-soluble $(\beta$-carotene with vitamin $A$ activity, vitamin $E$ ) vitamins. Vitamin $E$ is the most abundant fat-soluble vitamin of nonsaponifiable lipids in many algae. Seaweed vitamins are important not only due to their biochemical functions and antioxidant activity but also due to other health benefits such as decreasing blood pressure (vitamin C), prevention of cardiovascular diseases ( $\beta$-carotene), or reducing the risk of cancer (vitamins $\mathrm{E}$ and $\mathrm{C}$, carotenoids) [2]. Vitamin $\mathrm{E}$ is one of the most important fat-soluble vitamins with a strong antioxidant activity. Its special function is lipid protection from peroxidation. It exists in eight forms: $\alpha, \beta, \gamma, \delta$-tocopherols and $\alpha, \beta, \gamma, \delta$ tocotrienols. The $\alpha$-forms showed the highest antioxidant effect [3]. Further, the connection of vitamin $\mathrm{E}$ and decrease of blood pressure was reported [4].

Algal products have been used in food, cosmetic and pharmaceutical industries. An expanding market for these products is a fact and is facing a new challenge of growing algae on a large scale without harming any further the marine environment. Bulgarian Black Sea coast is rich in algae, regarding biomass and algal biodiversity. Brown seaweeds (Cystoseira crinita and Cystoseira barbata) and green seaweeds (Ulva rigida and Cladophora vagabunda) are widespread along the coastal area. Seaweeds are still under-utilized in Bulgaria because the knowledge about their chemical composition is still limited. It was reported that Black Sea Ulva spp. and Cystoseira spp. extracts have antioxidative and antibacterial activities [5,6,7]. 
Table 1. Taxonomy of investigated algal species

\begin{tabular}{|l|l|l|l|l|}
\hline & Ulva rigida & Cladophora vagabunda & Cystoseira crinita & Cystoseira barbata \\
\hline Phylum & Chlorophyta & Chlorophyta & Ochrophyta & Ochrophyta \\
\hline Class & Ulvophyceae & Ulvophyceae & Phaeophyceae & Phaeophyceae \\
\hline Order & Ulvales & Cladophorales & Fucales & Fucales \\
\hline Genus & Ulva & Cladophora & Cystoseira & Cystoseira \\
\hline
\end{tabular}

However, information about fat soluble vitamins content in Black Sea algae is scarce. The main objective of this investigation was to determine and compare $\alpha$-tocopherol and ergocalciferol content in Ulva rigida, Cladophora vagabunda, Cystoseira barbata and Cystoseira crinita from Bulgarian Black Sea coast. The formal taxonomy of the seaweeds is shown in Table 1.

\section{Experimental}

\subsection{Algal samples}

Ulva rigida, Cladophora vagabunda, Cystoseira barbata and Cystoseira crinita samples were collected in October, 2011 from the region of Balchik, Bulgaria. All of the samples were harvested manually from their respective sites and then transported to the laboratory in wet tissue towels in an ice box. They were thoroughly cleaned to remove epiphytes and detritus attached to the fronds. Cleaned samples were frozen and stored at $-20^{\circ} \mathrm{C}$ prior to analysis. The moisture content was determined by oven method at $105^{\circ} \mathrm{C}$ until constant weight [8].

\subsection{Standards and reagents}

Ergocalciferol, $\alpha$-tocopherol and other HPLCgrade reagents were purchased from SigmaAldrich $^{\mathrm{TM}}$.

\subsection{Sample preparation}

Sample preparation was performed following the method described by Lopez-Cervantes et al. [9] with some modifications [10]. An aliquot of the homogenized tissue $(1.500 \pm 0.005 \mathrm{~g})$ was weighed into a glass tube with a screw cap and $1 \%$ of methanolic L-ascorbic acid and $1 \mathrm{M}$ methanolic potassium hydroxide were added. Six parallel samples of algal tissues were prepared and saponified at $80^{\circ} \mathrm{C}$ for 20 minutes. After cooling the lipids were extracted with n-hexane. The extracts, containing fat soluble vitamins were evaporated under nitrogen. The dry residue was dissolved in methanol and injected $(20 \mu \mathrm{L})$ into the HPLC system.

\subsection{HPLC conditions}

HPLC system (Thermo Scientific Spectra SYSTEM) equipped with RP analytical column (ODS2 Hypersil ${ }^{\mathrm{TM}}$ 250x4,6 mm, 5um), UV and FL detectors were used. The mobile phase was composed of 97:3 = methanol:water with flow rate $1.0 \mathrm{~mL} / \mathrm{min}$. The qualitative analysis was performed by comparing the retention times of standard solutions. Ergocalciferol was monitored by UV detection at $\lambda \max =265 \mathrm{~nm}$ (Fig. 1).

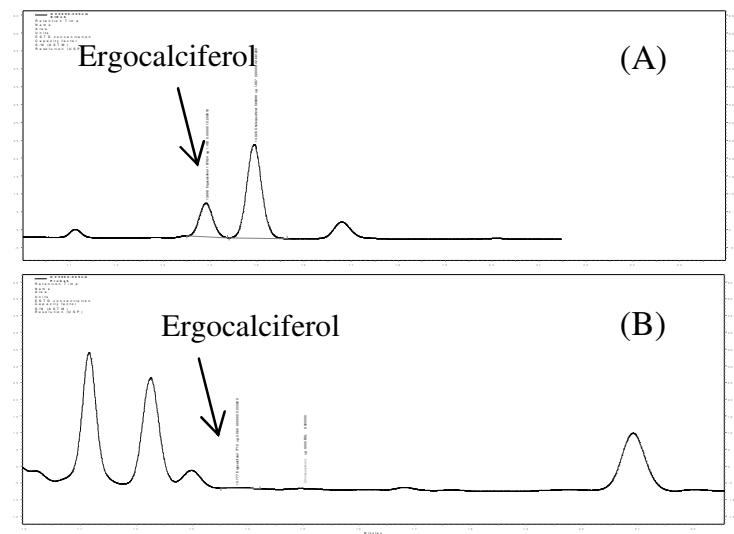

Fig. 1. HPLC chromatograms - UV detection (A) Standard solution (B) Sample Alpha-tocopherol was detected by fluorescence at $\lambda \mathrm{ex}=288 \mathrm{~nm}$ and $\lambda \mathrm{em}=332 \mathrm{~nm}$ (Fig. 2). 

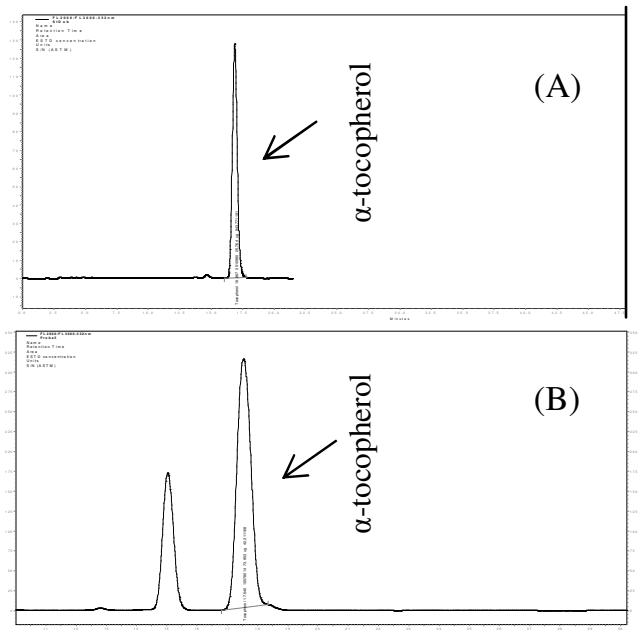

Fig. 2. HPLC chromatograms - FL detection (A) Standard solution (B) Sample

The quantitation was done by the method of the external calibration comparing the chromatographic peak areas of the samples with those of the corresponding standards.

\subsection{Statistical analysis}

All analytical determinations were performed in triplicate. The results were expressed as a mean and standard deviation (mean $\pm \mathrm{SD}$ ), and presented as $\mathrm{mg}$ per $100 \mathrm{~g}$ dry weight. Student's t-test was employed to estimate the significance of values. Statistical significance was indicated at $\mathrm{p}<0.05$.

\section{Results and Discussions}

Vitamin $\mathrm{E}$ is a generic term applied to the tocopherols and tocotrienols, which show similar nutritional properties to $\alpha$-tocopherol. In the present study significant differences $(\mathrm{p}<0.05)$ in alphatocopherol content between the four algal species were established (Table 2).

The results of the determination of $\alpha$-tocopherol in Ulva rigida, Cladophora vagabunda, Cystoseira barbata and Cystoseira crinita ranged between 1.68 and $29.13 \mathrm{mg}$ per $100 \mathrm{~g}$ d.w., reaching the highest content in Cystoseira barbata. Alpha-tocopherol content in this alga is approximately ten times higher than Ulva rigida and almost two times higher than Cystoseira crinita, which belongs to the same genus.

Table 2. Alpha-tocopherol and ergocalciferol contents in different algal species expressed as means \pm SD (mg per 100 g d.w.)

\begin{tabular}{|l|c|c|}
\hline Species & $\alpha$-tocopherol & Ergocalciferol \\
\hline $\begin{array}{l}\text { Ulva } \\
\text { rigida }\end{array}$ & $2.75 \pm 0.28^{\mathrm{a}}$ & $0.029 \pm 0.004$ \\
\hline $\begin{array}{l}\text { Cladophora } \\
\text { vagabunda }\end{array}$ & $1.68 \pm 0.38^{\mathrm{b}}$ & $\mathrm{nd}$ \\
\hline $\begin{array}{l}\text { Cystoseira } \\
\text { barbata }\end{array}$ & $29.13 \pm 1.08^{\mathrm{c}}$ & $\mathrm{nd}$ \\
\hline $\begin{array}{l}\text { Cystoseira } \\
\text { crinita }\end{array}$ & $16.67 \pm 1.73^{\mathrm{d}}$ & $\mathrm{nd}$ \\
\hline
\end{tabular}

n.d. - not detected;

a-d Values not sharing common superscript are significantly different at $\mathrm{p}=0.05$

The high content of $\alpha$-tocopherol in Cystoseira barbata may be associated with the higher amount of n-3 fatty acids, published in a previous study [11]. In brown algae the principal tocopherol is $\alpha$-tocopherol. Ergocalciferol was detected only in Ulva rigida samples.

Sanchez-Machado et al. [12] reported higher levels of $\alpha$-tocopherol in commercially important brown algae Himanthalia elongata. Alphatocopherol in dehydrated algae was $33.3 \mathrm{mg}$ per $\mathrm{g}$ d.w. and $12.0 \mathrm{mg}$ per $\mathrm{g}$ d.w. in canned samples, which clearly indicates the important effect of the processing on this compound. These authors referred that the levels recorded in these marine plants were superior to that registered in foods known as rich in $\alpha$-tocopherol.

Durmaz et al. [13, 14] obtained $\alpha$-tocopherol level $-17.10 \pm 0.10 \mu \mathrm{g}$ per $\mathrm{g}$ d.w. for macroalgae from Cystoseira spp. and $9.10 \pm 0.50 \mu \mathrm{g}$ per g d.w. for Ulva spp. These results are considerably lower than those obtained in the present study. 


\section{Conclusions}

Marine algae are generating a lot of interest because of their wide distribution and valuable chemical composition. In this work $\alpha$-tocopherol contents in four species of macroalgae from the Bulgarian Black Sea coast were investigated. The results showed that Ulva rigida, Cladophora vagabunda, Cystoseira crinita and especially Cystoseira barbata are a good source of $\alpha$ tocopherol and could be used as a vitamin E supplement.

\section{References}

*E-mail address: veselina.ivanova@ hotmail.com

[1]. K. Manivannan, G. Thirumaran, G. Karthikai Devi, A. Hemalatha and P. Anantharaman, American-Eurasian Journal of Botany 1(2), 3237 (2008).

[2]. S. Škrovánková, Seaweed Vitamins as Nutraceuticals, in Marine Medicinal Foods: Implications and Applications, Macro and Microalgae, ed. S.K. Kim, Advances in Food and Nutrition Research, USA, 2011, pp. $357-$ 369.

[3]. Y. Yamamoto, A. Fujisawa, A. Hara and W.C. Dunlap, Proceedings of the National Academy of Sciences of the United States of America 98, 13144 (2001).

[4]. M. Houston, Progress in Cardiovascular Diseases, 47(6), 396 (2005).
[5]. T. Negreanu-Pirjol, B. Negreanu-Pirjol, R. Sirbu, G. Paraschiv and A. Meghea, Journal of Environmental Protection and Ecology 13(3A), 1744 (2012).

[6]. V. Badea, D.P. Balaban, G. Rapeanu, C. Amariei and C.F. Badea, Romanian Biotechnological Letters 14(6), 4851 (2009).

[7]. C. Sava and R. Sirbu, Ovidius University Annals of Chemistry 21(1), 29-34 (2010).

[8]. AOAC, Official methods of analysis, 17th edition, Association of Official Analytical Chemists, Arlington VA, USA (2000).

[9]. J. Lopez-Cervantes, D.I. Sanchez-Machado and N.J. Rios-Vazquez, Journal of Chromatography A, 1105(1-2), 135 (2006).

[10]. D.A. Dobreva, B. Galunska and M. Stancheva, Scripta Scientifica Medica, Varna Medical University, 43(1), 276-279 (2011).

[11]. V. Ivanova, M. Stancheva and A. Merdzhanova, Ovidius University Annals of Chemistry 23(1), 35-40 (2012).

[12]. D. I. Sanchez-Machado, J. Lopez-Hernandez and P. Paseiro-Losada, Journal of Chromatography A, 976(1-2), 277-284 (2002).

[13]. Y. Durmaz, H. Duyar, S. Gokpinar, L. Taskaya, Y. Ogretmen, N. Bandarra and M. Nunes, International Journal of Natural and Engineering Sciences 2(3), 111-114 (2008).

[14]. Y. Durmaz, H. Duyar, S. Gokpinar, Y. Ogretmen and N. Bandarra, Journal of Fisheries Sciences 2(3), 350-356 (2008).

Submitted:April $11^{\text {th }} 2013$ Accepted in revised form: May $6^{\text {th }} 2013$ 